\title{
Hubungan Karakteristik Penderita dengan Gambaran Sitopatologi pada Kasus Karsinoma Paru yang Dirawat di RSUP Dr. M. Djamil Padang
}

\author{
Metha Arsilita Hulma, Masrul Basyar, Henny Mulyani
}

\begin{abstract}
Abstrak
Karsinoma paru merupakan tumor ganas epitel primer saluran nafas terutama bronkus yang dapat menginvasi struktur jaringan di sekitarnya dan berpotensi menyebar ke seluruh tubuh. Karakteristik penderita karsinoma paru dipengaruhi oleh berbagai faktor, diantaranya jenis kelamin, usia, status sosial ekonomi, kebiasaan merokok, dan gambaran sitopatologi. Penelitian ini bertujuan untuk mengetahui distribusi penderita karsinoma paru serta melihat hubungan antara karakteristik penderita dengan gambaran sitopatologi. Penelitian ini adalah deskriptif analitik dengan desain cross-sectional pada 128 penderita. Data yang digunakan adalah data sekunder dari laboratorium Patologi Anatomi dan Instalasi Rekam Medik. Data dianalisis dengan uji chi-square. Hasil analisis univariat menunjukkan penderita karsinoma paru sebagian besar laki-laki $(71,1 \%)$, kelompok usia $>40$ tahun $(85,2 \%)$, berlatar belakang pendidikan dasar $(49,2 \%)$, memiliki pekerjaan yang terpapar karsinogen $(53,9 \%)$, frekuensi terbesar pada penderita dengan Indeks Brikman berat $(49,2 \%)$, merupakan perokok aktif $(66,4 \%)$, dan jenis sel terbanyak adalah adenocarcinoma (47,7\%). Hasil analisis bivariat menunjukkan terdapat hubungan antara jenis kelamin dan riwayat merokok dengan gambaran sitopatologi $(p=0,022$ dan $p=0,000)$. Selain itu, tidak terdapat hubungan antara usia, latar belakang pendidikan, jenis pekerjaan, dan derajat berat merokok dengan gambaran sitopatologi ( $p=0,812$; $p=0,498 ; p=0,931$; dan $p=0,054)$.
\end{abstract}

Kata kunci: karsinoma paru, gambaran sitopatologi, karakteristik penderita

\begin{abstract}
Lung carcinoma is a malignant epithelial tumors in airway, especially primary bronchial that can invade surrounding tissue and potentially spread throughout the body. Characteristics of patient with lung carcinoma are influenced by various factors, including sex, age, socioeconomic status, smoking habits, and cytopathology overview. This study aimed to evaluate the distribution of patients with lung carcinoma and assess the relationship between the characteristics of patient with cytopathology overview. This study was descriptive analytical using cross-sectional study in 128 patients. We used secondary data derived from the Anatomic Pathology laboratory and the Medical Record Department. The data were analyzed by chi-square test. Results of univariate analysis showed patients with lung carcinoma mostly are male (71.1\%), > 40 years age group (85.2\%), background in basic educated people (49.2\%), had occupation contacted carcinogenic compound (53,9\%), the greatest frequency was found in patients with severe Brikman Index (49.2\%), active smokers (66.4\%), and most of cytopathology cell type are adenocarcinoma (47.7 \%). Results of bivariate analysis showed there are significant relationship between sex and smoking history with the overview of cytopathology $(p=0,022$ dan $p=0,000)$. In addition, there are no significant relationship between age, educational background, occupational history, and the degree of smoking with the overview of cytopathology ( $p=0,812$; $p=0,498 ; p=0,931$; dan $p=0,054$ ).
\end{abstract}

Keywords: lung carcinoma, cytopathology overview, characteristics of the patient

Affiliasi penulis : Fakultas Kedokteran Universitas Andalas

Korespondensi : Metha Arsilita Hulma, email

metha.arsilita@gmail.com, Telp: 085374715074

\section{PENDAHULUAN}

Saat ini terdapat lima penyakit paru (Big Five) dengan insiden terbesar yaitu karsinoma paru, penyakit paru obstruktif kronik (PPOK), tuberkulosis, pneumonia dan asma. ${ }^{1}$ Karsinoma paru atau yang umumnya dikenal sebagai kanker paru merupakan tumor ganas epitel primer saluran nafas terutama bronkus yang dapat menginvasi struktur jaringan di sekitarnya dan berpotensi menyebar ke seluruh tubuh melalui aliran darah dan sistem limfatik. ${ }^{2}$

Kanker paru merupakan tipe kanker yang menempati urutan pertama penyebab kematian setelah kanker payudara (16\%) dan kanker kolorektal $(10 \%){ }^{3} \quad \mathrm{Di}$ Indonesia, kanker paru menduduki peringkat ketiga diantara kanker yang paling sering ditemukan di beberapa rumah sakit. ${ }^{4}$

Menurut National Comprehensive Cancer Network tahun 2012, kanker paru diklasifikasikan dalam dua kategori umum yaitu Small Cell Lung Cancer (SCLC) dan Non-Small Cell Lung Cancer (NSCLC) yang merupakan tipe paling sering dari seluruh kanker paru (85\%). ${ }^{5}$

Data American Lung Association tahun 2004 mengungkapkan faktor risiko merokok menjadi $90 \%$ penyebab kematian kanker paru pada laki-laki dan perempuan. ${ }^{6}$ Penelitian terbaru membuktikan bahwa faktor kerentanan terhadap asap rokok, hormon estrogen, dan DNA memiliki peran penting terhadap karakteristik kanker paru pada perempuan. ${ }^{7}$ Adapun faktor risiko lain yang juga berpengaruh antara lain usia > 40 tahun, kontak erat dengan lingkungan asap tembakau (perokok pasif), lingkungan industri tertentu 
seperti asbestos, radiasi dari pekerjaan, obat-obatan, lingkungan, dan polusi udara. ${ }^{8}$ Diagnosis kanker paru dilakukan untuk menentukan jenis histopatologi kanker, lokasi tumor, serta penentuan stadium yang diperlukan untuk kepentingan pengobatan. ${ }^{2}$ Pemeriksaan sitologi merupakan salah satu pendekatan penting dan menjadi metode diagnosis yang baik dalam deteksi pertumbuhan kanker dan pemeriksaan sel kanker pra bedah. ${ }^{4}$

Tujuan penelitian ini adalah mengetahui hubungan antara karakteristik penderita dengan gambaran hasil sitopatologi pada kasus karsinoma paru yang dirawat di RSUP Dr. M. Djamil Padang.

\section{METODE}

Jenis penelitian adalah deskriptif analitik dengan desain cross-sectional. Populasi penelitian adalah seluruh catatan rekam medik penderita dengan gambaran hasil sitopatologi pada kasus karsinoma paru yang dirawat di RSUP Dr. M. Djamil Padang dari Januari 2010 sampai Desember 2012. Sampel berjumlah 128 orang. Kriteria inklusi adalah penderita yang didiagnosis karsinoma paru berdasarkan pemeriksaan sitopatologi dan dirawat di RSUP Dr. M. Djamil Padang. Kriteria eksklusi meliputi penderita yang memiliki data yang tidak lengkap dari catatan rekam medik di RSUP. Dr. M. Djamil Padang. Penelitian dilaksanakan dari bulan Desember 2012Desember 2013.

Variabel dependen penelitian adalah jenis kelamin, usia, pendidikan, pekerjaan, derajat berat merokok, dan riwayat merokok. Alat ukur yang digunakan berdasarkan data rekam medik sampel. Variabel independen adalah gambaran hasil sitopatologi. Data didapatkan melalui rekam medik sampel dengan hasil ukur meliputi (1) adenocarcinoma, (2) squamous cell carcinoma, (3) small cell carcinoma, (4) large cell carcinoma.

Langkah - langkah pengolahan data meliputi editing, coding, tabulating, processing, dan cleaning. Analisis data yang digunakan terdiri dari analisis univariat dan analisis bivariat. Pada analisis bivariat dilakukan dengan menggunakan uji statistik chisquare.
HASIL

1. Karakteristik Subjek Penelitian

Tabel 1. Distribusi Penderita Karsinoma Paru

\begin{tabular}{|c|c|c|c|}
\hline No & Karakteristik Penderita & Frekuensi & (\%) \\
\hline \multirow[t]{3}{*}{1.} & Jenis Kelamin & & \\
\hline & 1. Laki-laki & 91 & 71,1 \\
\hline & 2. Perempuan & 37 & 28,9 \\
\hline \multirow[t]{5}{*}{2.} & Usia & & \\
\hline & 1. $\leq 40$ tahun & 19 & 14,8 \\
\hline & 2. $>40$ tahun & 109 & 85,2 \\
\hline & Mean : 56,29 & & \\
\hline & SD $\quad: 13,30$ & & \\
\hline \multirow[t]{5}{*}{3.} & Pendidikan & & \\
\hline & 1. Tidak bersekolah & 12 & 9,4 \\
\hline & $\begin{array}{l}\text { 2. Pendidikan dasar (SD, } \\
\text { SMP) }\end{array}$ & 63 & 49,2 \\
\hline & $\begin{array}{l}\text { 3. Pendidikan menengah } \\
\text { (SMA) }\end{array}$ & 38 & 29,7 \\
\hline & $\begin{array}{l}\text { 4. Pendidikan tinggi (Diploma, } \\
\text { Sarjana, Magister, Doktor) }\end{array}$ & 15 & 11,7 \\
\hline \multirow[t]{11}{*}{4.} & Pekerjaan & & \\
\hline & $\begin{array}{l}\text { 1. Pekerjaan yang terpapar } \\
\text { karsinogen }\end{array}$ & 69 & 53,9 \\
\hline & $\begin{array}{l}\text { 2. Pekerjaan yang tidak } \\
\text { terpapar karsinogen }\end{array}$ & 59 & 46,1 \\
\hline & JUMLAH & 128 & 100 \\
\hline & $\begin{array}{l}\text { Pekerjaan yang terpapar } \\
\text { karsinogen } \\
\text { 1. ibu RT }\end{array}$ & 17 & 24,6 \\
\hline & 2. buruh bangunan & 8 & 11,6 \\
\hline & 3 pedagang, tukang masak & 4 & 5,8 \\
\hline & 4. petani, buruh tani & 32 & 46,6 \\
\hline & 5. montir (elektronik, sepeda) & 3 & 4,3 \\
\hline & 6. sopir, tukang ojek & 5 & 7,2 \\
\hline & JUMLAH & 69 & 100 \\
\hline \multirow[t]{3}{*}{5.} & $\begin{array}{l}\text { Derajat Berat Merokok (Indeks } \\
\text { Brinkman) } \\
\text { 1. Ringan }(0-200)\end{array}$ & 43 & 33,6 \\
\hline & 2. Sedang $(200-600)$ & 22 & 17,2 \\
\hline & 3. Berat $(>600)$ & 63 & 49,2 \\
\hline \multirow[t]{4}{*}{6.} & Riwayat Merokok & & \\
\hline & 1. Perokok aktif & 85 & 66,4 \\
\hline & 2. Perokok pasif & 35 & 27,3 \\
\hline & 3. Bekas perokok & 8 & 6,2 \\
\hline \multirow[t]{5}{*}{7.} & $\begin{array}{l}\text { Hasil Sitopatologi (Jenis } \\
\text { Karsinoma) }\end{array}$ & & \\
\hline & 1. Adenocarcinoma & 61 & 47,7 \\
\hline & $\begin{array}{l}\text { 2. Squamous cell } \\
\text { carcinoma }\end{array}$ & 52 & 40,6 \\
\hline & 3. Small cell carcinoma & 6 & 4,7 \\
\hline & 4. Large cell carcinoma & 9 & 7,0 \\
\hline & JUMLAH & 128 & 100 \\
\hline
\end{tabular}


Frekuensi penderita karsinoma paru dinilai berdasarkan hasil analisis univariat. Berdasarkan tabel 1 di atas, penderita karsinoma paru terbanyak adalah laki-laki $(71,1 \%)$, berusia $>40$ tahun $(85,2 \%)$, dan ratarata berusia 56,29 $\pm 13,30$ tahun. Penderita karsinoma paru terbanyak memiliki latar belakang pendidikan dasar $(49,2 \%)$, jenis pekerjaan yang terpapar oleh karsinogen $(53,9 \%)$, dan profesi sebagai petani $(46,6 \%)$. Derajat merokok kategori berat memiliki $(49,2 \%)$ dan riwayat merokok sebagai perokok aktif $(66,4 \%)$. Gambaran hasil sitopatologi berdasarkan jenis sel terbanyak adalah adenocarcinoma (47,7\%).

\section{Analisis Bivariat}

a. Hubungan Jenis Kelamin dengan Gambaran Sitopatologi

Tabel 2. Hubungan Jenis Kelamin terhadap Gambaran Sitopatologi

\begin{tabular}{|c|c|c|c|c|c|c|}
\hline \multirow{2}{*}{$\begin{array}{l}\text { Jenis } \\
\text { Kelam } \\
\text { in }\end{array}$} & \multicolumn{4}{|c|}{ Gambaran Sitopatologi } & \multirow[t]{2}{*}{ Total } & \multirow{2}{*}{$\begin{array}{l}\mathbf{P} \\
\text { Val } \\
\text { ue }\end{array}$} \\
\hline & $\begin{array}{l}\text { Adenoca } \\
\text { rcinoma }\end{array}$ & $\begin{array}{l}\text { Squa } \\
\text { mous } \\
\text { cell } \\
\text { carcin } \\
\text { oma } \\
\mathrm{n}(\%)\end{array}$ & $\begin{array}{l}\text { Small } \\
\text { cell } \\
\text { carcin } \\
\text { oma } \\
\mathrm{n}(\%)\end{array}$ & $\begin{array}{l}\text { Large } \\
\text { cell } \\
\text { carcin } \\
\text { oma } \\
\mathrm{n}(\%)\end{array}$ & & \\
\hline $\begin{array}{l}\text { Laki- } \\
\text { laki }\end{array}$ & $37(40,7)$ & $\begin{array}{c}44 \\
(48,4)\end{array}$ & $3(3,3)$ & $7(7,7)$ & $\begin{array}{c}91 \\
(100)\end{array}$ & $\begin{array}{l}0,0 \\
22\end{array}$ \\
\hline $\begin{array}{l}\text { Perem } \\
\text { puan }\end{array}$ & $24(64,9)$ & $\begin{array}{c}8 \\
(21,6)\end{array}$ & $3(8,1)$ & $2(5,4)$ & $\begin{array}{c}37 \\
(100)\end{array}$ & \\
\hline Total & $61(47,7)$ & $\begin{array}{c}52 \\
(40,6)\end{array}$ & $6(4,7)$ & $9(7,0)$ & $\begin{array}{c}128 \\
(100)\end{array}$ & \\
\hline
\end{tabular}

Sebagian besar penderita karsinoma paru yang dirawat berjenis kelamin laki-laki dengan jenis sel terbanyak yaitu squamous cell carcinoma (48,4\%). Nilai $p$ value $<0,05$ menunjukkan terdapat hubungan yang bermakna secara statistik antara jenis kelamin dengan gambaran sitopatologi.

\section{b. Hubungan Usia dengan Gambaran Sitopatologi}

Tabel 3. Hubungan Usia terhadap Gambaran Sitopatologi

\begin{tabular}{|c|c|c|c|c|c|c|}
\hline \multirow[t]{3}{*}{ Usia } & \multicolumn{4}{|c|}{ Gambaran Sitopatologi } & \multirow[t]{2}{*}{ Total } & \multirow{3}{*}{$\begin{array}{l}\mathbf{P} \\
\text { Val } \\
\text { ue }\end{array}$} \\
\hline & $\begin{array}{l}\text { Adenoca } \\
\text { rcinoma }\end{array}$ & $\begin{array}{l}\text { Squa } \\
\text { mous } \\
\text { cell } \\
\text { carcin } \\
\text { oma }\end{array}$ & $\begin{array}{l}\text { Small } \\
\text { cell } \\
\text { carcin } \\
\text { oma }\end{array}$ & $\begin{array}{l}\text { Large } \\
\text { cell } \\
\text { carcin } \\
\text { oma }\end{array}$ & & \\
\hline & $\mathrm{n}(\%)$ & $\mathrm{n}(\%)$ & $\mathrm{n}(\%)$ & $\mathrm{n}(\%)$ & $n \%)$ & \\
\hline $\begin{array}{l}\leq 40 \\
\text { tahun }\end{array}$ & $10(52,6)$ & $\begin{array}{c}6 \\
(31,6)\end{array}$ & $1(5,3)$ & $\begin{array}{c}2 \\
(10,5)\end{array}$ & $\begin{array}{c}19 \\
(100)\end{array}$ & $\begin{array}{l}0,8 \\
12\end{array}$ \\
\hline $\begin{array}{c}>40 \\
\text { tahun }\end{array}$ & $51(46,8)$ & $\begin{array}{c}46 \\
(42,2)\end{array}$ & $5(4,6)$ & $7(6,4)$ & $\begin{array}{c}109 \\
(100)\end{array}$ & \\
\hline Total & $61(47,7)$ & $\begin{array}{c}52 \\
(40,6)\end{array}$ & $6(4,7)$ & $9(7,0)$ & $\begin{array}{c}128 \\
(100)\end{array}$ & \\
\hline
\end{tabular}

Penderita karsinoma paru berusia $\leq 40$ dan $>$ 40 tahun memiliki jenis sel terbanyak adenocarcinoma dengan persentase masing-masing $52,6 \%$ dan $46,8 \%$.
Nilai $\mathrm{p}$ value $>0,05$ menunjukkan tidak terdapat hubungan yang bermakna secara statistik antara usia dengan gambaran sitopatologi.

\section{c. Hubungan Pendidikan dengan Gambaran Sitopatologi}

Tabel 4. Hubungan Pendidikan terhadap Gambaran Sitopatologi

\begin{tabular}{|c|c|c|c|c|}
\hline \multirow[t]{3}{*}{ Pendidikan } & \multicolumn{2}{|c|}{$\begin{array}{c}\text { Gambaran } \\
\text { Sitopatologi }\end{array}$} & Total & $\begin{array}{c}\mathrm{P} \\
\text { Value }\end{array}$ \\
\hline & $\begin{array}{c}\text { Adeno } \\
\text { carcino } \\
\text { ma }\end{array}$ & $\begin{array}{c}\text { Squam } \\
\text { ous } \\
\text { cell } \\
\text { carcino } \\
\text { ma }\end{array}$ & & \\
\hline & $\mathrm{n}(\%)$ & $\mathrm{n}(\%)$ & $\mathrm{n}(\%)$ & \\
\hline $\begin{array}{l}\text { Pendidikan } \\
\text { rendah }\end{array}$ & $\begin{array}{c}39 \\
(56,5)\end{array}$ & $\begin{array}{c}30 \\
(43,5)\end{array}$ & $69(100)$ & 0,498 \\
\hline $\begin{array}{c}\text { Pendidikan } \\
\text { tinggi }\end{array}$ & $22(50)$ & $22(50)$ & $44(100)$ & \\
\hline Total & $61(54)$ & $52(46)$ & $\begin{array}{c}113 \\
(100)\end{array}$ & \\
\hline
\end{tabular}

Latar belakang pendidikan rendah memiliki persentase terbesar pada jenis sel adenocarcinoma yaitu $56,5 \%$. Nilai $p$ value $>0,05$ menunjukkan tidak terdapat hubungan yang bermakna secara statistik antara latar belakang pendidikan dengan gambaran sitopatologi.

\section{d. Hubungan Pekerjaan dengan Gambaran Sitopatologi}

Tabel 5. Hubungan Pendidikan terhadap Gambaran Sitopatologi

\begin{tabular}{|c|c|c|c|c|c|c|}
\hline \multirow{3}{*}{$\begin{array}{c}\text { Pekerja } \\
\text { an }\end{array}$} & \multicolumn{4}{|c|}{ Gambaran Sitopatologi } & \multirow[t]{2}{*}{ Total } & \multirow{3}{*}{$\begin{array}{c}\mathrm{P} \\
\text { Valu } \\
e\end{array}$} \\
\hline & $\begin{array}{l}\text { Adeno } \\
\text { Carcino } \\
\text { ma }\end{array}$ & $\begin{array}{l}\quad \begin{array}{l}\text { Squamo } \\
\text { us }\end{array} \\
\text { cell } \\
\text { carcinom } \\
\text { a }\end{array}$ & $\begin{array}{l}\text { Small } \\
\text { cell } \\
\text { carcino } \\
\text { ma }\end{array}$ & $\begin{array}{l}\text { Large } \\
\text { cell } \\
\text { carcino } \\
\text { ma }\end{array}$ & & \\
\hline & $n(\%)$ & $n(\%)$ & $n(\%)$ & $\mathrm{n}(\%)$ & $\mathrm{n}(\%)$ & \\
\hline $\begin{array}{l}\text { Pekerja } \\
\text { an } \\
\text { yang } \\
\text { tidak } \\
\text { terpap } \\
\text { ar } \\
\text { karsino } \\
\text { ge }\end{array}$ & $\begin{array}{c}27 \\
(45,8)\end{array}$ & $\begin{array}{c}24 \\
(40,7)\end{array}$ & $3(5,1)$ & $5(8,5)$ & $\begin{array}{c}59 \\
(100)\end{array}$ & $\begin{array}{c}0,93 \\
1\end{array}$ \\
\hline $\begin{array}{l}\text { Pekerja } \\
\text { an } \\
\text { yang } \\
\text { terpap } \\
\text { ar } \\
\text { karsino } \\
\text { gen }\end{array}$ & $\begin{array}{c}34 \\
(49,3)\end{array}$ & $\begin{array}{c}28 \\
(40,6)\end{array}$ & $3(4,3)$ & $4(5,8)$ & $\begin{array}{c}69 \\
(100)\end{array}$ & \\
\hline Total & $\begin{array}{c}61 \\
(47,7) \\
\end{array}$ & $\begin{array}{c}52 \\
(40,6)\end{array}$ & $6(4,7)$ & $9(7)$ & $\begin{array}{c}128 \\
(100) \\
\end{array}$ & \\
\hline
\end{tabular}

Tabel 5 menunjukkan penderita karsinoma paru dengan jenis pekerjaan yang terpapar dan tidak terpapar karsinogen memiliki jenis sel terbanyak adenocarcinoma (49,3\% dan 45,8\%). Nilai $p$ value > 0,05 menunjukkan tidak terdapat hubungan yang bermakna secara statistik antara jenis pekerjaan dengan gambaran sitopatologi. Sebagian besar penderita memiliki jenis pekerjaan sebagai petani dan buruh tani serta ibu rumah tangga dengan jenis sel terbanyak adenocarcinoma (46,9\% dan 52,9\%). 


\section{e. Hubungan Derajat Berat Merokok dengan Gambaran Sitopatologi}

Tabel 6. Hubungan Derajat Berat Merokok terhadap Gambaran Sitopatologi

\begin{tabular}{|c|c|c|c|c|c|c|}
\hline \multirow{3}{*}{$\begin{array}{c}\text { Derajat } \\
\text { merokok }\end{array}$} & \multicolumn{4}{|c|}{ Gambaran Sitopatologi } & \multirow[t]{3}{*}{ Total } & \multirow{3}{*}{$\begin{array}{l}\mathrm{P} \\
\text { Val } \\
\text { ue }\end{array}$} \\
\hline & $\begin{array}{l}\text { Adenoca } \\
\text { rcinoma }\end{array}$ & $\begin{array}{l}\text { Squamo } \\
\text { us cell } \\
\text { carcinom } \\
\text { a }\end{array}$ & $\begin{array}{l}\text { Small } \\
\text { cell } \\
\text { carcin } \\
\text { oma }\end{array}$ & $\begin{array}{l}\text { Large } \\
\text { cell } \\
\text { carcino } \\
\text { ma } \\
\end{array}$ & & \\
\hline & $n(\%)$ & $n(\%)$ & $\mathrm{n}(\%)$ & $\mathrm{n}(\%)$ & & \\
\hline $\begin{array}{l}\text { Ringan- } \\
\text { Sedang } \\
\text { Berat }\end{array}$ & $\begin{array}{c}38 \\
(58,5) \\
23 \\
(36,5)\end{array}$ & $\begin{array}{c}19 \\
(29,2) \\
33 \\
(52,4)\end{array}$ & $\begin{array}{l}3(4,6) \\
3(4,8)\end{array}$ & $5(7,7)$ & $\begin{array}{c}65 \\
(100) \\
63 \\
(100)\end{array}$ & $\begin{array}{l}0,0 \\
54\end{array}$ \\
\hline Total & $\begin{array}{c}61 \\
(47,7)\end{array}$ & $\begin{array}{c}52 \\
(40,6)\end{array}$ & $6(4,7)$ & $9(7)$ & $\begin{array}{c}128 \\
(100)\end{array}$ & \\
\hline
\end{tabular}

Penderita karsinoma paru sebagaian besar memiliki derajat merokok kategori ringan-sedang dengan jenis sel terbanyak adenocarcinoma. Nilai $p$ value > 0,05 menunjukkan tidak terdapat hubungan yang bermakna secara statistik antara derajat berat merokok dengan gambaran sitopatologi.

\section{f. Hubungan Riwayat Merokok dengan Gambaran Sitopatologi}

Tabel 7. Hubungan Riwayat Merokok terhadap Gambaran Sitopatologi

\begin{tabular}{|c|c|c|c|c|c|c|}
\hline \multirow{3}{*}{$\begin{array}{l}\text { Riway } \\
\text { at } \\
\text { merok } \\
\text { ok }\end{array}$} & \multicolumn{4}{|c|}{ Gambaran Sitopatologi } & \multirow[t]{2}{*}{ Total } & \multirow{3}{*}{$\begin{array}{l}\mathbf{P} \\
\text { Val } \\
\text { ue }\end{array}$} \\
\hline & $\begin{array}{l}\text { Adenoca } \\
\text { rcinoma }\end{array}$ & $\begin{array}{l}\text { Squa } \\
\text { mous } \\
\text { cell } \\
\text { carcin } \\
\text { oma }\end{array}$ & $\begin{array}{l}\text { Small } \\
\text { cell } \\
\text { carcin } \\
\text { oma }\end{array}$ & $\begin{array}{l}\text { Large } \\
\text { cell } \\
\text { carcin } \\
\text { oma }\end{array}$ & & \\
\hline & $\mathrm{n}(\%)$ & n (\%) & $\mathrm{n}(\%)$ & $\mathrm{n}(\%)$ & $n \%)$ & \\
\hline $\begin{array}{c}\text { Perok } \\
\text { ok } \\
\text { aktif }\end{array}$ & $31(36,5)$ & $\begin{array}{c}45 \\
(52,9)\end{array}$ & $3(3,5)$ & $6(7,1)$ & $\begin{array}{c}85 \\
(100)\end{array}$ & $\begin{array}{l}0,0 \\
00\end{array}$ \\
\hline $\begin{array}{c}\text { Perok } \\
\text { ok } \\
\text { pasif- } \\
\text { bekas } \\
\text { perok } \\
\text { ok }\end{array}$ & $30(69,8)$ & $\begin{array}{c}7 \\
(16,3)\end{array}$ & $3(7)$ & $3(7)$ & $\begin{array}{c}43 \\
(100)\end{array}$ & \\
\hline Total & $61(47,7)$ & $\begin{array}{c}52 \\
(40,6)\end{array}$ & $6(4,7)$ & $9(7)$ & $\begin{array}{c}128 \\
(100)\end{array}$ & \\
\hline
\end{tabular}

Penderita dengan riwayat merokok aktif memiliki jenis sel squamous cell carcinoma sebagai jenis sel terbanyak. Nilai $p$ value yang didapatkan < 0,05 menunjukkan terdapat hubungan yang bermakna secara statistik antara riwayat merokok dengan gambaran sitopatologi.

\section{PEMBAHASAN}

\section{Karakteristik Subjek Penelitian}

Sebagian besar penderita karsinoma paru adalah laki-laki $(71,1 \%)$. Beberapa penelitian menyatakan bahwa kasus karsinoma paru lebih banyak pada laki-laki, seperti penelitian di RSUP $\mathrm{H}$. Adam Malik Medan tahun 2010 yang menunjukkan bahwa $73,3 \%$ penderita berjenis kelamin laki-laki. ${ }^{8}$ Lebih dari $50 \%$ laki-laki di Indonesia, China, Laos, Malaysia, dan Korea merupakan perokok aktif yang memiliki prevalensi dua kali lipat dari perokok aktif di Amerika Serikat. ${ }^{9}$

Pada penelitian ini didapatkan $85,2 \%$ penderita berusia > 40 tahun. Secara keseluruhan, rata-rata usia pasien sebesar $56,29 \pm 13,30$ tahun.
Nilai rata-rata usia pasien $>40$ tahun menandakan adanya kecenderungan peningkatan penderita karsinoma paru seiring dengan meningkatnya pertambahan usia. Hasil penelitian ini lebih rendah dibandingkan penelitian di RSUP Persahabatan Jakarta tahun 2011 yang menunjukkan $97 \%$ penderita karsinoma paru berusia 40 tahun ke atas. ${ }^{10}$ Menurut Kumar tahun 2004, usia merupakan faktor risiko penting terjadinya kanker. Insiden kanker semakin meningkat seiring dengan bertambahnya usia. Hal tersebut disebabkan karena semakin banyaknya pajanan faktor risiko dan kemampuan perbaikan sel yang semakin menurun. ${ }^{11}$

Penderita karsinoma paru terbanyak berasal dari latar belakang pendidikan dasar (SD, SMP) sebesar $49,2 \%$. Hasil penelitian ini sejalan dengan penelitian di RSUP Adam Malik Medan tahun 2012 yang menunjukkan bahwa $55,8 \%$ penderita karsinoma paru berasal dari latar belakang pendidikan dasar. ${ }^{12}$ Latar belakang pendidikan merupakan variabel penting yang menentukan penyerapan informasi oleh penderita karsinoma paru. Level pendidikan juga berhubungan dengan kemampuan seseorang dalam mengubah prilaku terhadap kesehatan dan pemanfaatan layanan kesehatan yang tersedia. ${ }^{13}$

Penderita karsinoma paru terbanyak berasal dari jenis pekerjaan yang terpapar karsinogen, yaitu $53,9 \%$. Adapun karsinogen yang memicu kejadian karsinoma paru berasal dari polusi udara dalam ruangan akibat pembakaran batu bara dan biomassa, agen di lingkungan pekerjaan seperti radon dan asbestos, logam berat seperti arsen, kadmium, kromium, nikel; polutan lingkungan yang berasal dari limbah berbahaya, emisi industri, dan pestisida pertanian. Persentase terbesar jenis pekerjaan yang terpapar oleh karsinogen adalah profesi petani dan ibu rumah tangga (46,6\% dan $24,6 \%)$. Hasil penelitian ini sejalan dengan penelitian yang dilakukan oleh Berliana tahun 2008 yang menunjukkan 49,1\% penderita karsinoma paru berasal dari profesi sebagai petani. $^{14}$

Pada penelitian didapatkan $49,2 \%$ penderita karsinoma paru memiliki derajat merokok kategori berat. Hasil ini sejalan sama dengan penelitian di RSUP H. Adam Malik Medan tahun 2012 yang menunjukkan sebagian besar penderita karsinoma paru memiliki derajat merokok kategori berat $(57,4 \%){ }^{12}$ Rosenberger dkk mempublikasikan penelitian pada tahun 2008 bahwa $73 \%$ penderita adalah perokok berat dengan rata-rata pack per years sebesar $32-49$ pada laki-laki. ${ }^{15}$

Pada penelitian ini didapatkan 66,4\% penderita karsinoma memiliki riwayat merokok sebagai perokok aktif. Hasil ini lebih rendah dibandingkan dengan penelitian di RSUP Persahabatan Jakarta tahun 2011 yang menunjukkan $78 \%$ penderita karsinoma paru memiliki riwayat merokok aktif. ${ }^{10} \mathrm{Di}$ beberapa negara seperti China terjadi peningkatan perokok aktif dalam dua dekade terakhir. Diperkirakan dua pertiga laki-laki dewasa China adalah perokok yang mewakili sepertiga perokok di seluruh dunia. ${ }^{16}$

Jenis sel karsinoma paru yang paling banyak didiagnosis pada penderita adalah adenocarcinoma $(47,7 \%)$. Penelitian lain yang dilakukan di RSUP $\mathrm{H}$. Adam Malik Medan tahun 2012 menunjukkan 57,3\% 
penderita karsinoma paru memiliki jenis sel adenocarcinoma. $^{12}$ Peningkatan adenocarcinoma diperkirakan karena adanya perubahan komposisi nikotin pada rokok dan penggunaan rokok filter dengan kadar tar yang rendah. ${ }^{17}$

\section{Analisis Bivariat}

a. Hubungan Jenis Kelamin dengan Gambaran Sitopatologi

Setelah dilakukan analisis chi-square diperoleh nilai $p$ value sebesar 0,022 yang menunjukkan terdapat hubungan yang bermakna antara jenis kelamin dengan gambaran sitopatologi. Hal serupa juga diperoleh dari penelitian di beberapa klinik kesehatan respirasi di Jerman tahun 2000-2003 yang menunjukkan bahwa jenis sel squamous cell carcinoma terbanyak pada laki-laki $(30 \%)$ sedangkan adenocarcinoma terbanyak pada perempuan (37\%). ${ }^{15}$

Penelitian yang dilakukan di National Taiwan University Hospital tahun 2000-2009 yang menunjukkan tidak terdapat perbedaan proporsi adenocarcinoma pada laki-laki maupun perempuan $(87,8 \%: 77,1 \%)$ dengan $p$ value $0,12 .^{18}$ Adanya peningkatan adenocarcinoma sejak tahun 1950 secara bertahap menunjukkan adanya perubahan kebiasaan merokok dan jenis konsumsi rokok yang sering terjadi pada laki-laki. Rokok yang dikonsumsi saat ini, sebagian besar mengandung kadar nikotin dan tar yang lebih rendah dari sebelumnya sehingga meningkatkan risiko tumor di daerah perifer seperti adenocarcinoma. $^{19}$

Setelah dilakukan analisis chi-square diperoleh nilai $p$ value sebesar 0,0812 yang menunjukkan tidak terdapat hubungan yang bermakna antara usia dengan gambaran sitopatologi. Hal serupa juga diperoleh dari penelitian yang dilakukan tahun 1991-1999 di Taiwan yang menunjukkan jenis sel adenocarcinoma ditemukan sebesar $77,9 \%$ pada usia $<40$ tahun, $67,6 \%$ pada usia $40-49$ tahun, $59,7 \%$ pada usia 50-59 tahun, dan kurang dari 50\% pada usia $>60$ tahun. Proporsi tertinggi penderita dengan adenocarcinoma terdapat pada usia $<40$ tahun dan squamous cell carcinoma pada usia $>80$ tahun. $^{19}$

Setelah dilakukan analisis chi-square diperoleh nilai $p$ value sebesar 0,498 yang menunjukkan tidak terdapat hubungan yang bermakna antara latar belakang pendidikan dengan gambaran sitopatologi. Hal ini sejalan dengan penelitian yang dilakukan oleh Mao Y dkk tahun 2001 pada 3280 penderita yang didiagnosis karsinoma paru. Hasil penelitian menunjukkan $53 \%$ penderita dengan level pendidikan yang lebih rendah memiliki kebiasaan merokok sebagai perokok aktif dengan jenis sel adenocarcinoma. ${ }^{20}$ Level pendidikan secara konsisten berhubungan dengan prilaku dan kebiasaan hidup, tetapi belum secara jelas diketahui mengenai jenis sel yang spesifik untuk level pendidikan tertentu. Hal ini lebih dipengaruhi oleh kebiasaan merokok pada penderita. $^{20}$

Pada analisis chi-square didapatkan nilai $\mathrm{p}$ value 0,931 yang menunjukkan tidak terdapat hubungan yang bermakna antara jenis pekerjaan dengan gambaran sitopatologi. Persentase penderita dengan karsinoma paru yang berhubungan dengan paparan karsinogen sulit untuk diestimasi dikarenakan cakupan yang luas mengenai intensitas paparan, riwayat genetik, dan riwayat merokok. Penjelasan lebih rinci mengenai jenis pekerjaan yang terpapar karsinogen pada penelitian ini menunjukkan sebagian besar penderita berprofesi sebagai petani dan ibu rumah tangga dengan jenis sel terbanyak adenocarcinoma (46,9\% dan 52,9\%). Hasil ini sejalan dengan penelitian di beberapa rumah sakit kanker di Andhra Pradesh tahun 2009-2010 pada 154 penderita dengan karsinoma paru. Proporsi tertinggi terdapat pada penderita yang memiliki pekerjaan yang terpapar oleh karsinogen sebesar $44,73 \%$ dan sebagian besar berlatar belakang sebagai pekerja di sektor pertanian. $^{21}$

Pada analisis chi-square diperoleh nilai $\mathrm{p}$ value sebesar 0,054 yang menunjukkan tidak terdapat hubungan yang bermakna antara derajat berat merokok dengan gambaran sitopatologi. Pada hasil penelitian, perokok kategori ringan-sedang memiliki proporsi terbesar dengan jenis sel terbanyak adenocarcinoma. Penelitian yang dilakukan di Universitas Marryland tahun 2010 menunjukkan bahwa merokok menjadi faktor risiko utama kejadian karsinoma paru yang terjadi akibat mutasi P53, gastrin-releasing peptide receptor (GRPR), epidermal growth factor receptor (EGFR), dan K-Ras. Mutasi KRas dan EGFR berhubungan dengan perkembangan jenis sel adenocarcinoma dan ditemukan pada $10 \%$ kasus adenocarcinoma. Namun, adanya pertambahan jumlah rokok yang dikonsumsi menyebabkan semakin banyak gen yang teraktivasi sehingga menyebabkan mutasi K-Ras mempengaruhi proliferasi sel bronkial pada karsinoma paru. ${ }^{22}$

Hasil analisis chi-square diperoleh nilai $p$ value 0,000 yang menunjukkan terdapat hubungan yang bermakna antara riwayat merokok dengan gambaran sitopatologi. Hasil yang sejalan diperoleh dari penelitian yang dilakukan di tiga rumah sakit di Singapura (Singapore General Hospital, Tan Tock Seng Hospital, dan National University Hospital) tahun 2000 yang menunjukkan insiden squamous cell carcinoma sebesar $63,33 \%$ dan adenocarcinoma sebesar $41,66 \%$ pada perokok. ${ }^{23}$ Penggunaan rokok filter berkadar tar rendah dan tinggi kadar nitrat menjadi salah satu penyebab peningkatan insiden adenocarcinoma dan penurunan insiden squamous cell carcinoma di Amerika Serikat. Asap rokok dengan kandungan polycyclic aromatic hydrocarbons yang rendah berhubungan dengan kejadian squamous cell carcinoma sedangkan asap rokok dengan kandungan nitrat dan agen toksik seperti nitrosamin berhubungan erat dengan adenocarcinoma. ${ }^{23}$

Berdasarkan penelitian ini dapat disimpulkan terdapat hubungan antara jenis kelamin dan riwayat merokok dengan gambaran sitopatologi pada penderita karsinoma paru. Di samping itu, tidak terdapat hubungan antara usia, latar belakang pendidikan, jenis pekerjaan, dan derat berat merokok dengan gambaran sitopatologi pada penderita karsinoma paru.

\section{DAFTAR PUSTAKA}

1. Susanto AD, Prasenohadi, Faisal Y. The Year of lung. Respiratory Dis. 2010 (diunduh 20 Maret 2013). Tersedia dari: URL: HYPERLINK http://jurnalrespirologi.org/jurnal/Jan10/Lung\%20of \%20the\%20year-2.pdf.

2. Perhimpunan Dokter Paru Indonesia. kanker paru jenis karsinoma bukan sel kecil. Pedoman 
Diagnosis dan Penatalaksanaan di Indonesia. Jakarta: Metro Offset Printing; 2011.

3. Baldwin DR, Richard BH. Lung cancer: early diagnosis and screening. Cancer Science and Therapy J. 2012; 7(2).

4. Pohan MY. Akurasi pemeriksaan sitologi dan histopatologi pada pasien kanker paru di beberapa rumah sakit Jakarta tahun 2000-2005 (tesis). Jakarta: Fakultas Kedokteran Universitas Indonesia; 2005.

5. Youlden DR, Susanna MC, Peter DB. The international epidemiology of lung cancer: geographical distribution and secular trends. Journal of Thoracis Oncology. 2008; 3(8): 819-31.

6. American Lung Association. Smoking-attributable lung cancer. Lung Cancer Fact Sheet. 2004.

7. Kuang $P$, Xuejun K. Lung cancer in Asian women. North American Journal of Medicine and Science. 2009 (diunduh 19 September 2013). Tersedia dari: URL: HYPERLINK http://najms.net/wpntent/uploads/v02i02p069.pdf.

8. Christine N. Hubungan merokok dengan kanker paru di RSUP Haji Adam Malik tahun 2009. Medan: Fakultas Kedokteran Universitas Sumatera Utara; 2010.

9. Hertz RP, Margaret MD, Susan WP. The burden of cancer in Asia. Pfizer J. 2008 (diunduh 22 September 2013). Tersedia dari: URL: HYPERLINK http://www.pfizer.com/files/products/cancer in asia .pdf.

10. Nuraini P. Faktor risiko kanker paru di RSUP Persahabatan Jakarta tahun 2009-2010. Jakarta: Fakultas Kedokteran dan IImu Kesehatan UIN Syarif Hidayatullah; 2011.

11. Kumar V, Anirban M. Paru dan saluran nafas atas: Buku Ajar Patologi. Edisi ke-7. Jakarta: Penerbit Buku Kedokteran EGC; 2004.

12. Saragih. Profil penderita kanker paru yang dirawat di Rindu A3 (RA3) RSUP H. Adam Malik Medan Tahun 2007-2010. Medan: Fakultas Kedokteran Universitas Sumatera Utara; 2012.

13. Lawson JM, Mitzi MS, Travonia H, Susanne A. The Relationship between lung cancer patients' educational level and evaluation of their treatment information needs. Journal of Cancer Education. 2009 (diunduh 13 November 2013). Tersedia dari: URL: HYPERLINK http://www.ncbi.nlm.nih.gov/pubmed/19838897.
14. Situmeang B. Karakteristik penderita kanker paru yang dirawat inap di RS. St. Elisabeth Medan Tahun 2004-2007. Medan: Fakultas Kesehatan Masyarakat Universitas Sumatera Utara; 2008.

15. Rosenberger A, Thomas I, Katrin K, Norman K, Vera Z, Gabi W, et al. Do genetic factors protect for early onset lung cancer? a case control study before the age of 50 years. Journal of BMC Cancer. 2008 (diunduh 11 November 2013). Tersedia dari: URL: HYPERLINK http://www.ncbi.nlm.nih.gov/pmc/articles/PMC229 $2731 /$.

16. Molina, Ping Y, Stephen DC, Steven ES, Alex AA. Non-small cell lung cancer: epidemiology, risk factors, treatment, and survivorship. Mayo Clinic Journal. 2008 (diunduh 14 November 2013).

17. Kadara H, Mohamed K, Ignacio I. Pulmonary adenocarcinoma: a renewed entity in 2011. Asian Pacific Society of Respirology J. 2012.

18. Hsu CL et al. Advanced non-small cell lung cancer in patients aged 45 years or younger: outcomes and prognostic factors. Journal of BMC Cancer. 2012.

19. Chen F, Haley J, William F. Lung adenocarcinoma incidence rates and their relation to motor vehicle density. American Asssociation for Cancer Research J. 2009 (diunduh 22 Oktober 2013). Tersedia dari: URL: HYPERLINK http://www.ncbi.nlm.nih.gov/pubmed/19273483.

20. Mao Y, Jinfu H, Anne MU, Robert S, Shirley F. Socioeconomic status and lung cancer risk in canada. international journal of epidemiology. 2001 (diunduh 14 November 2013). Tersedia dari: URL: HYPERLINK http://www.ncbi.nlm.nih.gov/pubmed/11511609.

21. Kirmani N, K Jamil, MUR Naidu. Occupational and environmental carcinogens in epidemiology of lung cancer in South Indian Population. Journal Biology and Medicine. 2010; 2(4).

22. Kligerman S, Charles W. Epidemiology of lung cancer in women: risk factors, survival, and screening. American Journal of Roentgenology. 2010; 196(2).

23. Seow $A$, Wee-Teng $P$, Ming $T$. Fumes from meat cooking and lung cancer risk in women. Journal American Association for Cancer Research. 2000 (diunduh 12 Desember 2013). Tersedia dari: URL: HYPERLINK http://cebp.aacrjournals.org/content/9/11/1215.full. 